\title{
Analisis Faktor Internal Pemanfaatan Pelayanan Poliklinik Gigi di UPT Puskesmas Kintamani VI Kabupaten Bangli
}

\author{
Ni Putu Sri Widayati, Ni luh Gde Ari Natalia Yudha, I Putu Dedy Kastama Hardy \\ Fakultas Ilmu Kesehatan Sains dan Teknologi, Universitas Dhyana Pura
}

\begin{abstract}
Abstrak
Latar Belakang: Prevalensi karies gigi di wilayah kerja UPT Puskesmas Kintamani VI masih tinggi sedangkan yang mendapatkan pelayanan kesehatan jumlahnya masih sedikit. Berbagai faktor dapat mempengaruhi tingkat pemanfaatan Puskesmas oleh masyarakat dalam mengatasi kesehatannya dari faktor internal maupun faktor eksternal Puskesmas. Tujuan dari penelitian ini untuk menganalisis faktor internal pemanfaatan pelayanan di UPT Puskesmas Kintamani VI dengan mendeskripsikan aspek kekuatan dan kelemahan yang dimiliki oleh UPT Puskesmas Kintamani VI.

Metode: Metode yang digunakan untuk pengumpulan data adalah kuesioner dan wawancara. Dengan jumlah sampel 32 orang pegawai UPT Puskesmas Kintamani VI, dua orang informan utama yaitu kepala puskesmas, dokter gigi dan tiga orang informan pendukung yaitu kepala tata usaha, PJ Upaya Kesehatan Perorangan, dan PJ gudang obat. Desain penelitian ini adalah mixed method dengan waktu pengumpulan data pada Bulan April sampai Bulan Mei Tahun 2020

Hasil: Berdasarkan analisa Matriks IFAS kekuatan utama yang dimiliki oleh UPT Puskesmas Kintamani VI, memiliki kebijakan internal dalam mengatur pemanfaatan pelayanan, memiliki alokasi dana untuk pelayanan di poliklinik gigi, dan memiliki SDM yang berkompeten dengan nilai skor 0,328 sedangkan kelemahan utama yang dimiliki oleh UPT Puskesmas Kintamani VI adalah sarana dan prasarana yang kurang dalam memberikan pelayanan di poliklinik gigi dengan nilai skor 0,082.

Kesimpulan: Skor analisis faktor internal yang dimiliki UPT Puskesmas Kintamani VI sebesar 3,064 lebih besar dari 2,5 sebagai nilai tertimbang, artinya organisasi UPT Puskesmas Kintamani VI memiliki kekuatan untuk menghadapai kelemahan yang dimiliki.
\end{abstract}

Kata kunci: Faktor Internal, Pelayanan Gigi, SWOT

\section{Internal Factors Analysis of Dental Polyclinic Service Utilization at UPT Puskesmas Kintamani VI Bangli Regency}

\begin{abstract}
Background: The prevalence of dental caries in the working area of UPT Kintamani Community Health Center (CHC) VI is high and low health services coverage. Various factors can affect the level of utilization of $\mathrm{CHC}$ by the community in dealing with their health from internal factors and external factors at the CHC. This study aimed to analyze the internal factors of service utilization at the UPT Kintamani CHS VI by describing the strengths and weaknesses of the UPT Kintamani CHC VI.

Methods: The methods for data collection were questionnaires and interviews. Total sample are 32 of employees of the UPT Kintamani CHC VI, two main informants were the head of the CHC, a dentist and three supporting informants, namely the head of administration, person in charge of individual health effort, and person in charge of drug store. This is mixed method study with data collection time during April to May 2020

Result: Based on the IFAS Matrix analysis, the main strengths was from the UPT Kintamani CHC VI, have internal policies in regulating service utilization, have allocation of funds for services in dental polyclinics, and have competent human resources with a score of 0.328 while the main weaknesses possessed by UPT Kintamani CHC VI is the facilities and infrastructure that are lacking in providing services at the dental polyclinic with a score of 0.082

Conclusion: The score of internal factor analysis owned by UPT Kintamani CHC VI is 3.064, greater than 2.5 as a weighted value, meaning that UPT Kintamani CHC VI has the strength to deal with its weaknesses.

Keywords: Internal Factors, Dental Services, SWOT.

Korespondensi: Ni Putu Sri Widayati

Email: Widayatisri880@gmail.com
\end{abstract}




\section{PENDAHULUAN}

Kesehatan gigi dan mulut masyarakat di Indonesia masih perlu mendapatkan perhatian tenaga kesehatan baik dokter maupun perawat gigi. Riset Kesehatan Dasar (Riskesdas) Tahun 2018 menyebutkan bahwa prevalensi nasional masalah kesehatan gigi dan mulut adalah 57,6\% dan yang mendapatkan pelayanan tenaga kesehatan adalah sebesar $10,2 \%{ }^{1} \quad$ Target pemanfaatan Puskesmas di Indonesia yang ditetapkan Departemen Kesehatan RI adalah sembilan orang perhari, sedangkan kenyataannya di Indonesia kunjungan masyarakat ke poliklinik gigi di Puskesmas masih dikategorikan rendah. ${ }^{2}$

Berdasarkan data yang di peroleh dari UPT Puskesmas Kintamani VI, pasien yang berkunjung ke poliklinik gigi pada tahun 2019 adalah 942 orang, dengan diagnosis karies gigi disertai gusi bengkak sebanyak 462 orang dan dengan diagnosa gangguan penyakit gigi dan mulut lainnya sebanyak 480 orang. Data tersebut menunjukkan pemanfaatan pelayanan di poliklinik gigi di tahun 2019 hanya 6,7\% dan rata-rata kunjungan perhari tiga orang pasien dan masih di bawah target nasional yaitu sembilan orang perhari. Berbagai faktor dapat mempengaruhi tingkat pemanfaatan Puskesmas oleh masyarakat dalam mengatasi permasalahan kesehatan baik yang berasal dari internal Puskesmas maupun faktor eksternal. Faktor internal Puskesmas meliputi aspek kekuatan dan kelemahan. Aspek kekuatan meliputi kekuatan atau keunggulan dalam melaksanakan pelayanan yang dimiliki oleh organisasi seperti sumber daya manusia, dana, sarana dan prasarana. Sedangkan aspek kelemahan seperti keterbatasan sumber daya manusia, sarana prasana, dana dan lain sebagainya. Sedangkan faktor eksternal yang mempengaruhi pemanfaatan Puskesmas adalah adanya sebuah ancaman dan kesempatan atau peluang yang bersumber dari lingkungan organisasi. Strategi ini dikenal dengan analisis SWOT (Strenght, Weaknesses, Opportunities, Threats). ${ }^{3}$

Penelitian analisis SWOT tentang pemanfataan pelayanan di Puskesmas oleh masyarakat telah banyak dilakukan. Penelitian yang dilakukan oleh Yuliani pada tahun 2015 yang meneliti tentang analisis SWOT pada pelayanan gizi Puskesmas Temon I, Kecamatan Temon, Kabupaten Kulon Progo menyatakan bahwa ketersediaan tenaga gizi yang kompeten merupakan kekuatan yang dimiliki Puskesmas Temon. Kelemahannya adalah kurangnya fasilitas terutama alat - alat kesehatan sesuai standar yang dipersyaratkan. ${ }^{3}$ Rendahnya pemanfaatan pelayanan poliklinik gigi di UPT Puskesmas Kintamani VI oleh masyarakat, apabila tidak dilakukan penanganan dengan tepat akan berdampak pada rendahnya tingkat kesehatan gigi masyarakat di wilayah kerja UPT Puskesmas Kintamani VI. Agar dapat dilakukan upaya atau strategi yang tepat perlu diakukan analisis faktor internal terkait hal tersebut. Tujuan penelitian ini adalah untuk mengalisis faktor internal pemanfaatan pelayanan poliklinik gigi di UPT Puskesmas Kintamani VI.

\section{METODE}

Penelitian ini merupakan penelitian mixed method dengan pendekatan eksplanatoris sekuensial. Penelitian ini dilaksanakan di Puskesmas Kintamani VI Kecamatan Kintamani, Kabupaten Bangli pada bulan April hingga Mei 2020. Pengambilan sampel dalam penelitian ini menggunakan teknik purposive sampling. Sampel dalam penelitian kuantitatif menggunakan teknik total sampling yaitu seluruh pegawai UPT Puskesmas Kintamani VI sebanyak 35 orang. Pada saat penelitian terdapat dua orang pegawai sudah pindah tugas dan satu orang pegawai adalah peneliti jadi sampel penelitiannya sebanyak 32 orang Sedangkan informan pada penelitian kualitatif dibagi menjadi dua kriteria di antaranya informan utama yaitu koordinator poliklinik gigi yang meliputi dokter gigi dan Kepala Puskesmas UPT Puskesmas Kintamani VI dan informan triangulasi yang dipergunakan oleh peneliti sebagai informan dalam mengecek kredibilitas data yang diperoleh dari informan utama. Informan yang dipilih yaitu kepala urusan tata usaha, Penanggung jawab Upaya Pelayanan Perorangan (PJ.UKP) dan penanggung jawab gudang obat.

Data-data yang telah diolah kemudian dianalisis menggunakan aplikasi komputer. Data primer dari hasil kuesioner berupa pembobotan dan pemeringkatan (rating) pada faktor internal pemanfaatan pelayanan di poliklinik gigi di UPT Puskesmas Kintamani VI dan data sekunder disajikan dalam bentuk naratif deskriptif. Analisis data yang digunakan pada penelitian ini adalah analisis SWOT, yaitu menganalisis faktor internal kekuatan dan kelemahan yang dimiliki oleh UPT Puskesmas Kintamani VI dalam pemanfaatan pelayanan di poliklinik gigi dengan menggunakan matrik 
IFAS (Internal Strategic Factor Analisis Summary), yang didapatkan dari perkalian antara bobot faktor dengan rating. Setelah menentukan skor dari tiap variabel, maka diketahui untuk skor total faktor internalnya, sehingga hal tersebut dapat menyusun strategi ke depannya. Setelah menganalisis hal tersebut maka langkah selanjutnya adalah menentukan strategi SWOT. Penelitian ini sudah mendapatkan persetujuan etik dari pihak Universitas Dhyana Pura dan Puskesmas Kintamani VI.

\section{HASIL}

Karakteristik Responden

Tabel 1 Karakteristik Responden

\begin{tabular}{llcc}
\hline \multicolumn{2}{c}{ Karakteristik responden } & Frekuensi & Persentase \\
\hline Jenis & Laki-laki & 6 & 18,7 \\
Kelamin & Perempuan & 26 & 81,3 \\
Pendidikan & SMA/SMK & 4 & 12,5 \\
& Diploma & 24 & 75 \\
& Sarjana & 4 & 12,5 \\
\multirow{4}{*}{ Umur } & $<30$ & 5 & 15,6 \\
& $30-40$ & 20 & 62,5 \\
& $>40$ & 7 & 21,9 \\
\hline
\end{tabular}

Berdasarkan Tabel 1 diketahui dari 32 responden dalam penelitian ini yang berjenis kelamin laki-laki sebanyak enam orang $(18,7 \%)$ dan yang berjenis kelamin perempuan sebayak 26 orang $(81,3 \%)$. Karakteristik berdasarkan tingkat pendidikan responden dapat diketahui lulusan SMA/SMK sebanyak empat orang $(12,5 \%)$, lulusan diploma sebanyak 24 orang (75\%), dan lulusan sarjana sebanyak empat orang $(12,5 \%)$. Karakteristik berdasarkan golongan umur dapat diketahui responden dengan golongan umur kurang dari 30 tahun $(<30)$ sebanyak lima orang $(15,6 \%)$, golongan umur 30 - 40 tahun sebanyak 20 orang $(62,5 \%)$, serta golongan umur di atas 40 tahun sebanyak tujuh orang $(21,9 \%)$.

\section{Identifikasi Aspek Kekuatan dan Kelemahan Berdasarkan Hasil Wawancara}

Berdasarkan Tabel 2, aspek kekuatan pada sumber daya manusia, dokter gigi dan perawat gigi di UPT Puskesmas Kintamani VI sudah mengikuti pelatihan dan seminar tentang pelayanan kesehatan gigi. Hal ini didukung oleh pernyataan dari dokter gigi sebagai berikut:

"Saya mengikuti pelatihan tentang pelayanan kesehatan gigi di Puskesmas terakhir pada tahun 2018 dan mengikuti seminar terakhir pada Januari 2020” (Informan 1).

Tabel 2. Identifikasi Kekuatan dan Kelemahan

\begin{tabular}{|c|c|c|c|}
\hline No & $\begin{array}{c}\text { Aspek } \\
\text { Internal }\end{array}$ & Kekuatan & Kelemahan \\
\hline 1 & SDM & $\begin{array}{l}\text { 1. Memiliki dokter } \\
\text { gigi dan perawat } \\
\text { gigi yang } \\
\text { berkompeten di } \\
\text { bidangnya } \\
\text { 2. Memiliki dokter } \\
\text { gigi dan perawat } \\
\text { gigi yang ramah } \\
\text { dalam } \\
\text { memberikan } \\
\text { pelayanan }\end{array}$ & $\begin{array}{lr}\text { 1.Memiliki } & \text { SDM } \\
\text { yang minim dan } \\
\text { ada tugas } \\
\text { tambahan } \\
\begin{array}{l}\text { lainnya } \\
\text { harus yang } \\
\text { dilaksanakan }\end{array}\end{array}$ \\
\hline 2 & $\begin{array}{c}\text { Sarana dan } \\
\text { prasarana }\end{array}$ & $\begin{array}{l}\text { 1. Memiliki ruang } \\
\text { bermain anak } \\
\text { 2. Memiliki dental } \\
\text { unit yang modern }\end{array}$ & $\begin{array}{lr}\text { 1.Bahan } & \text { habis } \\
\text { pakai } & \text { untuk } \\
\text { perawatan } & \text { gigi } \\
\text { jumlahnya } & \\
\text { terbatas. } & \\
\end{array}$ \\
\hline 3 & Dana & $\begin{array}{l}\text { Memiliki alokasi } \\
\text { pembiayaan dalam } \\
\text { pengadaan sarana } \\
\text { dan prasarana di } \\
\text { Poliklinik Gigi }\end{array}$ & - \\
\hline 4 & Manajemen & 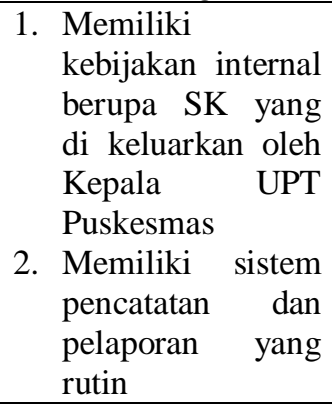 & - \\
\hline
\end{tabular}

Untuk aspek kekuatan pada sarana dan prasarana, berdasarkan hasil wawancara dengan Kepala Tata Usaha (KTU), Penanggung jawab Usaha Kesehatan Perorangan (PJ.UKP), dan dokter gigi menyatakan bahwa alur pengadaan dan 'pengamprahan' obat yaitu diamprahkan oleh koordinator poliklinik gigi ke penanggung jawab gudang obat, kemudian penanggung jawab gudang obat membuat LPLPO ke Dinas Kesehatan untuk amprahan obat dan bahan habis pakai di poliklinik gigi yang dilalukan setiap bulan sekali, setelah LPLPO dikirim ke 
Dinas Kesehatan. Dan ada juga beberapa alat dan bahan yang diamprahkan setahun sekali menggunakan dana kapitasi dari JKN, dan harus menggunakan E-Katalog. Hal ini didukung oleh pernyataan dari Penanggung Jawab Gudang Obat sebagai berikut:

"Saya menerima amprahan bahan dan obat dari poliklinik gigi, kemudian saya amprahkan ke Dinas Kesehatan Kabupaten menggunakan LPLPO, dilakukan setiap bulan sekali. dan ada amprahan alat dan bahan yang dilakukan setiap satu tahun sekali dan harus menggunakan daftar E- Katalog” (Informan 5).

Selanjutnya, berdasarkan hasil wawancara mengenai aspek kekuatan pada pembiayaan dan manajemen, pembiayaan dalam pengadaan alat dan bahan di poliklinik gigi adalah menggunakan dana APBD Kabupaten, JKN, APBN dan BOK. Dana dari APBD (belanja tidak langsung dana dari JKN). Kepala Puskesmas sudah membuat beberapa kebijakan baik secara langsung maupun tidak langsung mempengaruhi pemanfaatan pelayanan poliklinik gigi di UPT Puskesmas ini. Hal ini didukung oleh pernyataan dari Kepala UPT Puskesmas Kintamani VI sebagai berikut:

"Saya membuat beberapa kebijakan yang terkait dengan pelayanan Kesehatan di Puskesmas Kintamani VI"
Berdasarkan Tabel 2, aspek kelemahan pada sumber daya manusia, selain bertugas di poliklinik gigi, dokter gigi dan perawat gigi juga memiliki tanggung jawab terhadap program lainnya dan jika ada kegiatan luar gedung secara bersamaan, maka terkadang di poliklinik gigi kosong. Hal ini didukung oleh pernyataan dokter gigi di UPT Puskesmas Kintamani VI yaitu:

"Selain saya bertugas di poliklinik gigi, saya juga memiliki tanggung jawab terhadap program UKS dan memiliki daerah binaan, begitu juga dengan perawat giginya, sehingga jika kami ada kegiatan luar gedung yang berbarengan, poliklinik gigi kosong tidak ada petugas yang berjaga, sehingga pelayanan di poliklinik pada hari tersebut tidak ada" (Informan 1).

Sedangkan untuk aspek kelemahan pada sarana dan prasarana berdasarkan hasil wawancara, dokter gigi menyatakan bahwa bahan habis pakai untuk pelayanan di poliklinik gigi jumlahnya sangat terbatas, sehingga menghambat dalam proses pelayanan kesehatan gigi, dan juga beberapa tindakan seperti penambalan gigi tidak bisa dilakukan dikarenakan bahan tambalan gigi tidak ada serta UPT Puskesmas Kintamani VI memiliki ruang tunggu yang masih tergabung dengan ruang tunggu poliklinik lainnya.

Tabel Matrix IFAS (Internal Factor Analisis Summary)

Tabel 3. Kekuatan Matrix IFAS

\begin{tabular}{|c|c|c|c|c|}
\hline \multicolumn{2}{|r|}{ Kekuatan/Strength } & \multirow{2}{*}{$\frac{\text { Bobot }}{0,082}$} & \multirow{2}{*}{ Skor } & \multirow{2}{*}{$\begin{array}{c}\text { Total Skor } \\
0,328\end{array}$} \\
\hline $\mathrm{S} 1$ & $\begin{array}{l}\text { Memiliki kebijakan yang mengatur } \\
\text { pemanfaatan pelayanan }\end{array}$ & & & \\
\hline $\mathrm{S} 2$ & $\begin{array}{l}\text { Memilliki dokter gigi dan perawat gigi } \\
\text { yang berkompeten }\end{array}$ & 0,082 & 4 & 0,328 \\
\hline $\mathrm{S} 3$ & Memiliki dental unit yang sudah modern & 0,061 & 4 & 0,244 \\
\hline $\mathrm{S} 4$ & $\begin{array}{l}\text { Memiliki ruang tunggu yang cukup } \\
\text { nyaman dan ada area bermain anak }\end{array}$ & 0,061 & 3 & 0,183 \\
\hline S5 & $\begin{array}{l}\text { Memiliki dokter gigi dan perawat gigi } \\
\text { yang ramah }\end{array}$ & 0,061 & 3 & 0,183 \\
\hline S6 & $\begin{array}{l}\text { Adanya alokasi dana kapitasi untuk } \\
\text { kegiatan pelayanan di Poliklinik Gigi }\end{array}$ & 0,082 & 4 & 0,328 \\
\hline S7 & $\begin{array}{l}\text { Adanya system pencatatan dan pelaporan } \\
\text { yang rutin pada pemanfaatan pelayanan } \\
\text { di Poliklinik Gigi }\end{array}$ & 0,082 & 4 & 0,328 \\
\hline & Total skor kekuatan & & & 1,902 \\
\hline
\end{tabular}


Tabel 4. Kelemahan Matrix IFAS

\begin{tabular}{|c|c|c|c|c|}
\hline \multicolumn{2}{|r|}{ Kelemahan/weakneses } & \multirow{2}{*}{$\frac{\text { Bobot }}{0,061}$} & \multirow{2}{*}{$\frac{\text { Skor }}{2}$} & \multirow{2}{*}{$\frac{\text { Total Skor }}{0,122}$} \\
\hline $\mathrm{W} 1$ & Jumlah dokter gigi yang minim & & & \\
\hline $\mathrm{W} 2$ & Jumlah Perawat gigi yang Minim & 0,061 & 2 & 0,122 \\
\hline W3 & Jumlah bahan habis pakai terbatas & 0,082 & 1 & 0,082 \\
\hline W4 & $\begin{array}{l}\text { Memiliki ruang tunggu yang masih gabung } \\
\text { dengan pasien di poliklinik lain }\end{array}$ & 0,061 & 4 & 0,244 \\
\hline W5 & Air untuk pelayanan masih agak susah & 0,061 & 4 & 0,244 \\
\hline W6 & $\begin{array}{l}\text { Pengadaan bahan tambal gigi harus } \\
\text { menggunakan e katalog }\end{array}$ & 0,082 & 1 & 0,082 \\
\hline W7 & $\begin{array}{l}\text { Terkadang Poliklinik Gigi kosong dikarenakan } \\
\text { dokter gigi dan perawat gigi ada tugas di luar } \\
\text { Gedung Puskesmas }\end{array}$ & 0,082 & 3 & 0,246 \\
\hline & Total skor kelemahan & & & 1,142 \\
\hline
\end{tabular}

Berdasarkan Tabel 3 dan 4 menyatakan jumlah nilai total faktor internal (total skor IFAS) adalah 3,044 di mana lebih besar dari 2,5 sebagai nilai tertimbang. Ini berarti organisasi UPT Puskesmas Kintamani VI memiliki faktor internal yang kuat. Hal ini juga didukung oleh hasil perhitungan skor kekuatan dan kelemahan, dengan rumus $\mathrm{S}-\mathrm{W}=\mathrm{x}$.

Berdasarkan dari hasil pengolahan kuesioner pada Tabel 3 dan 4, Tabel Matrix IFAS didapatkan nilai skor kekuatan sebesar 1,902 dan nilai skor kelemahan 1,142 sehingga selisih antara nilai skor kekuatan dengan nilai skor kelemahan adalah 0,76. Hal ini menunjukkan bahwa nilai aspek kekuatan lebih besar 0,76 dari nilai total skor aspek kelemahan. Sehingga hal ini menunjukkan bahwa faktor internal yang positif dengan kekuatan lebih besar dari kelemahannya.

\section{PEMBAHASAN}

Aspek Kekuatan

SDM kesehatan menurut Sistem Kesehatan Nasional (SKN) yang dikutip oleh Adisasmito, adalah tatanan yang menghimpun berbagai upaya perencanaan, pendidikan dan pelatihan serta terpadu dan saling mendukung, guna menjamin tercapainya derajat kesehatan masyarakat yang setinggi-tingginya. ${ }^{4}$ UPT Puskesmas Kintamani VI memiliki dokter gigi dan perawat gigi yang berkompeten di bidangnya untuk memberikan pelayanan gigi. Petugas selalu berusaha untuk meningkatkan kompetensinya di bidang pelayanan kesehatan gigi dengan mengikuti pelatihan dan seminar sehingga dapat memberikan pelayanan yang berkualitas. Hal ini merupakan kekuatan utama yang dimiliki oleh UPT Puskesmas Kintamani VI dengan nilai skor 0,328 .

Hal ini sejalan dengan hasil penelitian dari Muhammad Iqbal Fahlevi dengan judul Pengaruh Kompetisi Petugas Terhadap Kinerja Pelayanan Kesehatan di Puskesmas Peuteumeue Kabupaten Aceh Barat, yang menunjukkan bahwa ada pengaruh antara pengetahuan petugas kesehatan terhadap kinerja pelayanan Kesehatan di Puskesmas Peureumeue Kecamatan Kaway XVI Kabupaten Aceh Barat. ${ }^{5}$

Dilihat dari aspek pembiayaan, menurut Rivai dan Arifin pembiayaan atau financing adalah pendanaan yang di berikan oleh suatu pihak kepada pihak lain untuk mendukung investasi yang telah direncanakan, baik dilakukan sendiri maupun lembaga. ${ }^{6}$ UPT Puskesmas Kintamani VI memiliki anggaran pembiayaan dalam pengadaan alat dan bahan di poliklinik gigi yaitu menggunakan dana APBD Kabupaten, JKN, APBN dan DAK/BOK. Dana dari APBD (belanja tidak langsung dana dari JKN). Tujuan dari adanya alokasi dana tersebut untuk meningkatkan pelayanan kesehatan. Merupakan kekuatan utama yang di miliki oleh UPT Puskesmas Kintamani VI dengan nilai skor 0,328

Hal ini sejalan dengan penelitian dari Ulma Putri Septyantie dkk yang berjudul Hubungan antara Realisasi Dana Bantuan Operasional Kesehatan dengan Indikator Gizi KIA di Kabupaten-Kota Provinsi Jawa Tengah yang menyatakan realisasi dana BOK berpengaruh positif terhadap indikator Gizi KIA di Kabupaten/Kota Provinsi Jawa Tengah ${ }^{7}$ dan juga sesuai dengan penelitian dari Estherlina Sitorus dkk, yang berjudul Analisis 
Pembiayaan Kesehatan Bersumber Pemerintah di Kota Serang Tahun 2014 - 2016 yang menyatakan sumber pembiayaan kesehatan di kota Serang sebagian besar dari APBD. ${ }^{8}$

Dilihat dari aspek sarana dan prasarana, menurut KBBI sarana adalah segala sesuatu yang dapat dipakai sebagai alat dalam mencapai maksud dan tujuan dan prasarana adalah segala sesuatu yang merupakan penunjang utama terselenggaranya suatu proses. ${ }^{9}$ Jadi sarana dan prasarana secara umum adalah suatu alat atau bagian yang memiliki peran penting untuk mencapai dan juga kelancaran dalam berbagai hal atau sebaliknya. Sarana dan prasarana menjadi satu hal yang sangat penting dan harus ada dalam proses untuk menghasilkan yang sesuai dengan harapan. Poliklinik Gigi di UPT Puskesmas Kintamani VI memiliki dental unit yang cukup modern sehingga memudahkan dalam penggunaannya dan akan membantu peningkatan mutu pelayanan di Poliklinik Gigi di UPT Puskesmas Kintamani VI serta memiliki ruang tunggu yang cukup nyaman dikarenakan memiliki ruang bermain anak sehingga anak yang berobat merasa senang dan tidak bosan menunggu antrean.

Hal ini sejalan dengan penelitian Nur Dwiana Sari Saudi tentang Efisiensi dan Pandangan Etis terhadap Penggunaan Teknologi Modern dalam Menunjang Pelayanan Kesehatan yang menyatakan bahwa penggunaan alat kedokteran yang modern akan membantu meningkatkan mutu pelayanan medis dan pelayanan non-medis. ${ }^{10}$ Penelitian ini juga sesuai dengan penelitian Ida Yuniari tentang Pengaruh Sarana Prasarana dan Kualitas Pelayanan Terhadap Kepuasan Pasien yang menyatakan bahwa terdapat hubungan sarana dan prasarana terhadap kepuasan pasien. ${ }^{11}$

Dilihat dari aspek manajemen, manajemen puskesmas adalah rangkaian kegiatan yang bekerja secara sistematik untuk menghasilkan keluaran yang efektif dan efisien. Manajemen Puskesmas meliputi perencanaan, pelaksanaan, pengendalian, pengawasan pertanggung jawaban, yang harus dilaksanakan secara terkait dan berkesinambungan. ${ }^{12}$ Kepala UPT Puskesmas Kintamani VI membuat beberapa kebijakan baik secara langsung maupun tidak langsung mempengaruhi pemanfaatan pelayanan Poliklinik Gigi, sehingga dapat mengatur kegiatan pelayanan di Poliklinik Gigi. Kekuatan utama UPT Puskesmas adalah sudah memiliki kebijakan tentang pemanfaatan pelayanan di Poliklinik Gigi dengan skor sebesar 0,328.

Hasil penelitian ini sesuai dengan penelitian Yusni Ainurrahmah tentang Pengaruh Manajemen Pusat Kesehatan Masyarakat terhadap Akses pelayanan Kesehatan untuk Mewujudkan Mutu Pelayanan Kesehatan yang menyatakan bahwa manajemen pusat kesehatan masyarakat di pengaruhi aspek pelayanan kesehatan dan mutu pelayanan Kesehatan. ${ }^{13}$

\section{Aspek Kelemahan}

Hasil wawancara di UPT Puskesmas Kintamani VI memiliki satu orang dokter gigi dan satu orang perawat gigi, selain itu dokter gigi dan perawat gigi selain bertugas di poliklinik gigi, mereka juga memiliki tugas pokok tambahan yang harus dikerjakan yaitu sebagai pemegang program dan memiliki daerah binaan masing-masing, sehingga jika ada jadwal kegiatan yang berbarengan yang berhubungan dengan program tersebut menyebabkan poliklinik gigi tidak ada petugas jaga. Pasien yang berobat pada hari tersebut tidak mendapatkan pelayanan, sehingga pasien yang berkunjung pada saat itu merasa kecewa. Dengan petugas di poliklinik gigi yang jumlahnya minimal ditambah dengan adanya tugas pokok tambahan kepada mereka menjadikan tidak fokus untuk pelayanan di poliklinik gigi saja karena mereka juga harus menyelesaikan tugas pokok lainnya. Hal ini merupakan kelemahan utama yang di miliki oleh UPT Puskesmas Kintamani VI dengan nilai skor 0,122 . Hal ini sejalan dengan penelitian dari Rusda Irawati dkk di tahun 2017, tentang Analisis Pengaruh Beban Kerja Terhadap Kinerja Karyawan Operator pada PT Giken Precision Indonesia dengan hasil penelitian bahwa beban kerja eksternal berupa tugas, lingkungan kerja dan sikap kerja menunjukkan adanya pengaruh negatif terhadap kinerja karyawan. ${ }^{14}$

Berdasarkan hasil wawancara yang diperoleh bahwa bahan habis pakai di poliklinik gigi jumlahnya sangat terbatas, sehingga menghambat dalam pelayanan di poliklinik gigi, bahkan dikarenakan bahan-bahan untuk tambalan gigi tidak ada, maka pasien yang datang tidak mendapatkan pelayanan penambalan gigi, terpaksa dirujuk ke rumah sakit untuk mendapatkan perawatan gigi. Hal tersebut merupakan kelemahan utama yang dimiliki oleh UPT Puskesmas Kintamani VI dengan nilai skor .yang Berhubungan dengan 
Pemanfaatan Pelayanan Kesehatan di UPTD Puskesmas Langara Kecamatan Wawonnii Barat, Kabupaten Konawe Kepulauan dengan hasil penelitian menyatakan bahwa ada hubungan yang signifikan sarana dan prasarana terhadap pemanfaatan pelayanan kesehatan. ${ }^{15}$

\section{Analisis Matrix IFAS}

Total skor faktor internal UPT Puskesmas Kintamani VI yaitu 3,044 di mana lebih besar dari 2,5 sebagai nilai tertimbang. Hal ini juga didukung oleh hasil perhitungan skor kekuatan dan kelemahan, dengan rumus $\mathrm{S}-\mathrm{W}=\mathrm{x}$. Berdasarkan dari hasil pengolahan kuesioner pada tabel 3 dan 4 didapatkan nilai skor kekuatan sebesar 1,902 dan nilai skor kelemahan 1,142 sehingga selisih antara nilai skor kekuatan dengan nilai skor kelemahan adalah 0,76 . Hal ini menunjukkan bahwa nilai aspek kekuatan lebih besar 0,76 dari nilai total skor aspek kelemahan. Sehingga hal ini menunjukkan bahwa faktor internal yang positif dengan kekuatan lebih besar dari kelemahannya.

Hal ini menunjukkan UPT Puskesmas Kintamani VI memiliki faktor internal yang kuat di mana dengan kekuatan yang dimiliki akan dapat mengatasi kelemahan yang ada sehingga mampu meningkatkan mutu pelayanan dengan memberikan kepuasan terhadap pelanggan atau pasien di UPT Puskesmas Kintamani VI. Hasil penelitian ini di dukung oleh teori Freddy Rangkuti yang menyatakan selisih total kekuatan di kurangi dengan selisih total kelemahan $(\mathrm{S}-\mathrm{W}=\mathrm{x})$, jika $\mathrm{S}$ atau kekuatan lebih besar dari nilai $\mathrm{W}$ atau kelemahan nilai $\mathrm{X}$ akan positif, sehingga mampu untuk mengatasi kelemahan yang ada dalam organisasi. ${ }^{16}$ Penelitian ini juga didukung oleh penelitian Achmad Rizal dkk tentang Analisis Faktor Internal Penentu kepuasan Pasien Puskesmas Kota Banjarmasin yang menyatakan bahwa faktor internal mempunyai hubungan yang bermakna terhadap kepuasan pasien. ${ }^{17}$

\section{KESIMPULAN}

Aspek kekuatan/strenght dalam pemanfaatan pelayanan poliklinik gigi yang dimiliki oleh UPT Puskesmas Kintamani VI adalah memiliki kebijakan yang mengatur pemanfaatan pelayanan di poliklinik gigi, memiliki SDM yang berkompeten, dan memiliki alokasi dana dalam peningkatan pelayanan di poliklinik gigi. Sedangkan aspek kelemahan/ weakness dalam pemanfaatan pelayanan poliklinik gigi yang dimiliki oleh UPT
Puskesmas Kintamani VI adalah terbatasnya SDM dan sarana dan prasarana terutama bahan habis pakai.

\section{DAFTAR PUSTAKA}

1. Kementerian Kesehatan RI. Riskesdas 2018 [Internet]. Riset Kesehatan Dasar 2018. 2018 [dikutip 15 Maret 2020]. hal. 182-3. Tersedia pada: http://www.kesmas.kemkes.go.id/assets/upl oad/dir_519d41d8cd98f00/files/Hasilriskesdas-2018_1274.pdf

2. Yosa A, Wahyuni S. Faktor-Faktor Yang Berhubungan Dengan Kunjungan Pelayanan Gigi Di Puskesmas Way Laga Kota Bandar Lampung. J Anal Kesehat Vol 4, No 2 Sept 2015. 2015;4(2):420-6.

3. Yuliani. Analisis Pada Pelayanan Gizi Puskesmas Temon I Kecamatan Temon, Kabupaten Kulon Progo. [Skripsi]. Yogyakarta: Universitas Muhammadiyah Yogyakarta; 2015

4. Adisasmito, W. Sistem Kesehatan. Jakarta: PT. Raja Grafindo Persada; 2007

5. Fahlevi MI. Pengaruh Kompetensi Petugas Terhadap Kinerja Pelayanan Kesehatan di Puskesmas Peuruemeue Kabupaten Aceh Barat; 2017

6. Rivai V, Arifin A. Islamic Banking. Bumi Aksara; 2010.

7. Septyantie UP, Cahyadin M. Hubungan Antara Realisasi Dana Bantuan Operasional Kesehatan dengan Indikator Gizi KIA di Kabupaten/Kota Provinsi Jawa Tengah Tahun 2012. Vol. 02, Jurnal Kebijakan Kesehatan Indonesia. 2013.

8. Sitorus E, Nurwahyuni A, et al. Analisis Pembiayaan Kesehatan Bersumber Pemerintah di Kota Serang. [Skripsi]. Depok: Universitas Indonesia; 2017

9. KBBI, 2016. Kamus Besar Bahasa Indonesia (KBBI). [Online] Available at: http://kbbi.web.id/pusat

10. Saudi ND. Efisiensi dan Pandangan Etis terhadap Penggunaan Teknologi Modern dalam Menunjang Pelayanan Kesehatan; 2010

11. Yuniari I, Ristiani, et al. Pengaruh Sarana Prasarana dan Kualitas Pelayanan terhadap Kepuasan pasien Rawat Jalan Unit Poliklinik IPDN Jati Negara. [Skripsi]. IPDN : Jatinegsra; 2017

12. Depkes RI. Permenkes RI tentang Pedoman Manajemen Puskesmas. 2016. 
13. Ainurrahmah Y. Pengaruh Manajemen Pusat Kesehatan Masyarakat terhadap Akses Pelayanan Kesehatan untuk Mewujudkan Mutu Pelayanan Kesehatan [Internet]. Vol. 11, Jurnal Publik: Jurnal Ilmiah Bidang Ilmu Administrasi Negara. 2017 Jun [dikutip 9 Desember 2020]. Tersedia pada: www.journal.uniga.ac.id

14. Irawati R, Carollina DA. Analisis Pengaruh Beban Kerja terhadap Kinerja Karyawan Operator pada PT Giken Precision Indonesia. Inovbiz J Inov Bisnis [Internet]. 15 Juni 2017 [dikutip 9 Desember 2020];5(1):51-8. Tersedia pada: http://ejournal.polbeng.ac.id/index.php/IBP /article/view/171

15. Wulandari C, Ahmad LO, Saputra SK, et. al. Faktor yang Berhubungan dengan Pemanfaatan Pelayanan Kesehatan di UPTD Puskesmas Langara Kecamatan Wawoni Barat Kabupaten Konawe Kepulauan; 2016

16. Rangkuti F. SWOT Balanced Scorecard, Jakarta: PT Gramedia Pustaka Utama; 2011

17. Rizal A, Jalpi A. Analisis Faktor Internal Penentu Kepuasan Pasien Puskesmas Kota Banjarmasin [Skripsi]. Banjarmasin: Universitas Kalimantan Muhammad Arsyad Al Banjari Banjarmasin; 2018

18. Echols J, Hassan S. Kamus InggrisIndonesia. Jakarta: Gramedia Pustaka Utama; 2000

19. Gambaran Umum Puskesmas Kintamani VI. Profil Puskesmas Kintamani VI; 2019
20. ]Morita S, Asykarie IN. Kontrol Kualitas Poliklinik Gigi di RS PKU Muhammadiyah Delagu menggunakan Analisa SWOT. [Skripsi]. Surakarta: Universitas Muhammadiyah; 2017

21. Permenkes RI Tentang Kinik. Depkes RI. 2011; 28

22. Permenkes RI tentang Standar Pelayanan Keteknisian Gigi. Depkes RI. 2015; 32

23. Permenkes RI tentang Standar Sarana dan Prasarana di Klinik Gigi. Depkes RI. 2016; 52

24. Permenkes RI tentang Upaya Kesehatan Gigi dan Mulut. Depkes RI. 2015; 89

25. Radito TA. Analisis Pengaruh Kualitas Pelayanan dan Fasilitas Kesehatan Terhadap Kepuasan Pasien Puskesmas. Yogyakarta; 2014

26. Sastrianegara MF. Organisasi dan Manjemen Pelayanan Kesehatan. Jakarta: PT. Salemba Medika; 2016

27. Subaktiah Y, Kuswardani N, Yuwanti S, et al. Analisis SWOT Faktor Internal dan Eksternal pada Pengembangan Usaha Gula Merah Tebu Kabupaten Bondowoso [Skripsi]. Jember: Universitas Jember; 2018

28. Sugiyono. Metode Penelitian Kualitatif. Bandung: Alfabeta; 2016

29. Undang-Undang Republik Indonesia Tentang Kesehatan. Departemen Kesehatan RI. 2009; 36 